\title{
APPLICATION OF ANTI-CRISIS MEASURES BY THE BANKS OF UKRAINE ABOUT THE PROVISION OF BANKING SERVICES IN THE CONTEXT OF A PANDEMIC OF CORONAVIRUS
}

\author{
Kushnir S. O., Hevorhyan H. A. \\ Zaporizhzhia National University \\ Ukraine, 69600, Zaporizhzhia, Zhykovsky str., 66 \\ unicornuniuni1@gmail.com \\ SvetlanaAK@ukr.net \\ ORCID 0000-0002-1410-1887
}

Key words:

bank, banking, bank services, development, crisis, crisis management.
This article discusses the concept of «anti-crisis regulation» and considers methods and instruments of such regulation, defines the main direction of the development of banking services in crisis conditions. The activities of commercial banks in the current unstable economic environment have been analyzed. The article explores the functions and economic influence of commercial banks at the micro level, proposes methods for improving banking services according to the current economic environment. Methods and approaches to the formation of stable development of banking services in Ukraine during the crisis have been proposed.

In a market economy, banks play a key role in sustaining the economy, acting as profit-making institutions and make their own risk decisions. The complications of bank's actions and the increasing competition in the banking market, which operates under difficult economic conditions (particularly in times of crisis), make it necessary to monitor banks performance and the quality of the services provided. Consequently, all aspects of both government intervention and selfregulation should be explored and taken into account in the regulation of the banking market.

The relevance of this study lies in the identification of external and internal factors affecting the economy and the banking system in particular, as well as in the analysis and forecasting of the correct steps in the regulation of banking services and the further development of the banking sector in Ukraine.

\section{ЗАСТОСУВАННЯ БАНКАМИ УКРАЇНИ АНТИКРИЗОВИХ ЗАХОДІВ ЩОДО НАДАННЯ БАНКІВСЬКИХ ПОСЛУГ В УМОВАХ ПАНДЕМІЇ КОРОНАВІРУСУ}

\author{
Кушнір С. О., Геворгян Г. А. \\ Запорізький національний університет \\ Украӥна, 69600, м. Запоріжжя, вул. Жуковського, 66
}

\begin{abstract}
Ключові слова:
банк, банківський сектор, банківські послуги, розвиток, криза, антикризове регулювання.
\end{abstract}

У даній статті висвітлено поняття «антикризове регулювання» та розглянуто методи та інструменти такого регулювання, визначено основний напрям розвитку сфери банківських послуг в умовах кризи. Проаналізовано діяльність комерційних банків у сучасних нестабільних економічних умовах. У статті досліджено функції та економічний вплив комерційних банків на мікрорівні, запропоновано методи поліпшення банківських послуг згідно 3 актуальним економічним середовищем. Запропоновано методи та підходи до формування стабільного розвитку сфери банківських послуг в України в період кризи.

В умовах ринкової економіки банки відіграють ключову роль у підтримці економіки, виступають як інститути, діяльності яких спрямовано на одержання прибутку та які самостійно приймають рішення щодо власних ризиків. Ускладнення діяльності банків та зростання конкуренції на ринку банківських послуг, який функціонує в складних економічних умовах (зокрема в умовах кризи) обумовлює необхідність контролю за його діяльністю та якістю наданих послуг. А отже, при регулюванні ринку банківських послуг повинні бути досліджені та враховані усі аспекти застосування як державних заходів впливу, так і саморегулювання.

Актуальність даного дослідження полягає в виявленні зовнішніх та внутрішніх чинників, що впливають на економіку та на банківську систему зокрема, а також в аналізі та прогнозуванні вірних кроків регулювання банківських послуг та подальшого розвитку банківського сектору в Україні. 


\section{Statement of the problem}

According to the Law of Ukraine of 07.12.2000 №2121 III «About banks and banking activities» (hereinafter the Law), a bank is a legal person who, on the basis of a bank license, has the exclusive right to provide banking services, information about which is entered in the State Register of Banks [1]. Banks accumulate temporarily available funds of natural and legal persons, directing them to the economic field where funds are scarce.

The sudden events of 2019-2020 associated with the world's coronavirus pandemic have changed the economy at both the macro- and micro-levels. In the face of a drastic change in the economic situation, it is important to address the crisis by regulating economic entities and, in particular, the banking sector. This year's events have changed the economic realities in which Ukraine's banking system is functioning. Adapting to the new macro- and micro-economic conditions is now relevant for the banking sector.

\section{Analysis of recent studies and publications}

Anti-crisis banking regulation and development of banking services under crisis conditions were studied by foreign and domestic scientists such as O. Afanas'yeva, O. Baranovs'kyy, I.A. Blank, Dzh. K. Van Khorn, I.K. Kovankadze, Y. O. Botkin, A.YE. But, V. Vdovin, V. Bryshtina, A. Hradova, A. Hryaznova, O. Dzyublyuk, A. Yermoshenko, V. Kovalenko, O. Krukhmal', A. Moroz, V. Mishchenko, L. Perekhrest, M. Orlovs'ka, M. Savluk V.V. Popov, I.A. Trakhtenberh etc. In their writings, they, in particular, developed theoretical and methodological foundations for the formation of an anticrisis management system, investigated the activities of banks in the financial crisis, the conditions for the development and functioning of banks in unstable economic conditions, the mechanism for ensuring the quality of the loan portfolio and credit risk management of the bank in times of crisis in the economy and the problems of organizing bank lending in times of crisis in the economy.

\section{Objectives of the article}

The objective of this article is to study and to analyze the activities of the banking sector and, in particular, the services provided by banks in the context of the economic crisis. The study also compares the provision of banking services by the country's leading banks, their measures to combat and prevent the spread of coronavirus in the country.

\section{The main material of the research}

The turbulent events of 2020 «have turned the world and the world economy for 180 degrees. It has become clear that the spread of the virus will not only result in the loss of lives of a large part of the Earth's population, but will also lead to a deep global crisis, the consequences of which humanity will struggle for a long period of time.

The banking system is the most important sphere of national economy of any developed country. Its practical role is determined by the fact that banks manage the payment and settlement system in the country; most of bank's commercial transactions are conducted through deposits, investments and credit operations; together with other financial intermediaries, banks channel the savings of the population to firms and production structures. At the center of economic life, serving the interests of producers, banks mediate between industry and trade, agriculture and the population. The role of banks in further deepening and improving market relations in the country is enormous [2].

Depending on the entity, which regulate the banking system, regulation is separated into self-regulation and government regulation. The National Bank of Ukraine (NBU) is the body of state regulation of the market of banking services. The forms, methods and instruments of government regulation are aimed at ensuring the stability not only of the banking sector but also of the economy as a whole.

The purpose of self-regulating organizations is to ensure the effective operation of the professional participants who are their members, to develop and adopt rules and standards of professional conduct, implementation of the relevant professional activity, as well as the complex solution of problem issues, taking into account the views of market participants [3].

The difficult situation in the country is further complicated by the coronavirus pandemic, the suspension of many businesses, the increase in unemployment, the sharp drop in incomes, the decline in the fees and the creditworthiness of natural and legal persons, directly proportionally influences the emergence of banking crises. This situation calls for the introduction of specialized measures that make up the bank's crisis management.

Crisis management consists of using the full potential of modern management tools and techniques, taking into account the resource and time constraints of the crisis management process. In general, there are such areas of crisis management (Pic. 1) [14].

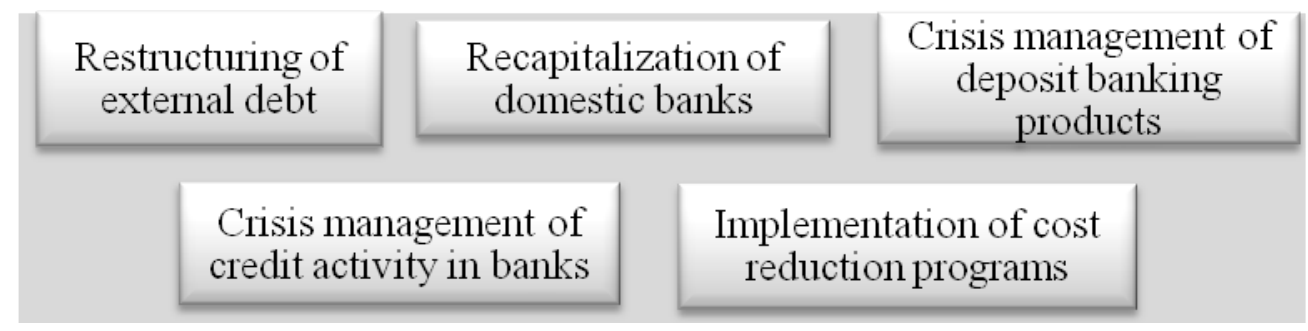

Figure 1 - Areas of crisis management of banking activities. Source: generated by the authors [1]. 
- Under article 47 of the Act, a bank has the exclusive right to carry out banking activities on the basis of a bank license by providing banking services. Banking services are as follows:

- 1) attracting funds (deposits) and bank metals from an unlimited number of legal and natural persons;

- 2) opening and maintenance of current (correspondent) customer accounts, including bank metals, and contingent (escrow) accounts;
- 3) placement of deposits (deposits), including current accounts, funds and bank metals, on their own terms and at their own risk [1].

- Table 1 shows the performance of banks for the 1st quarter of both 2019 and 2020. As we can see, the number of active banks has hardly changed. Bank assets have decreased by 181,384 million UAH, and loans to clients have increased by $48,343 \mathrm{UAH}$. The funds of individuals under the savings certificates have decreased by $67,965 \mathrm{UAH}$.

Tab.1 - Analysis of banking services for 1st quarter of both 2019 and 2020. Source: formed by authors according to data [4].

\begin{tabular}{|l|c|c|c|}
\hline \multicolumn{1}{|c|}{ Indicator } & \multicolumn{2}{l|}{ First quarter value } \\
\hline \multicolumn{1}{|c|}{ Change, $\%$} \\
\hline Amount of operating banks & 2019 & 2020 & $-2,6$ \\
\hline Assets (million UAH) & 77 & 75 & $+13,4$ \\
\hline Total assets (not adjusted for active reserves), million UAH & 1354702 & 1536086 & $+7,1$ \\
\hline Loans to costumers, million UAH & 1032703 & 1081046 & $+4,7$ \\
\hline Liabilities, million UAH & 1536086 & 1354702 & $-13,4$ \\
\hline $\begin{array}{l}\text { Funds of individuals (with savings (deposit) certificates),million } \\
\text { UAH }\end{array}$ & 579769 & 511804 & $-11,7$ \\
\hline
\end{tabular}

The NBU discount rate continues its downward trend (Pic. 2) [5].

The reduction of the NBU discount rate will reduce the yield of the Government's Deposit Certificates and Domestic Government Loan bonds, in which the banks have invested the money collected from the public through deposits. Accordingly, banks will have to divert money from deposits to lending to people and businesses, but at lower interest rates, as the cost of credit (through refinancing and certificates of deposit) is also pegged to the discount rate [6].

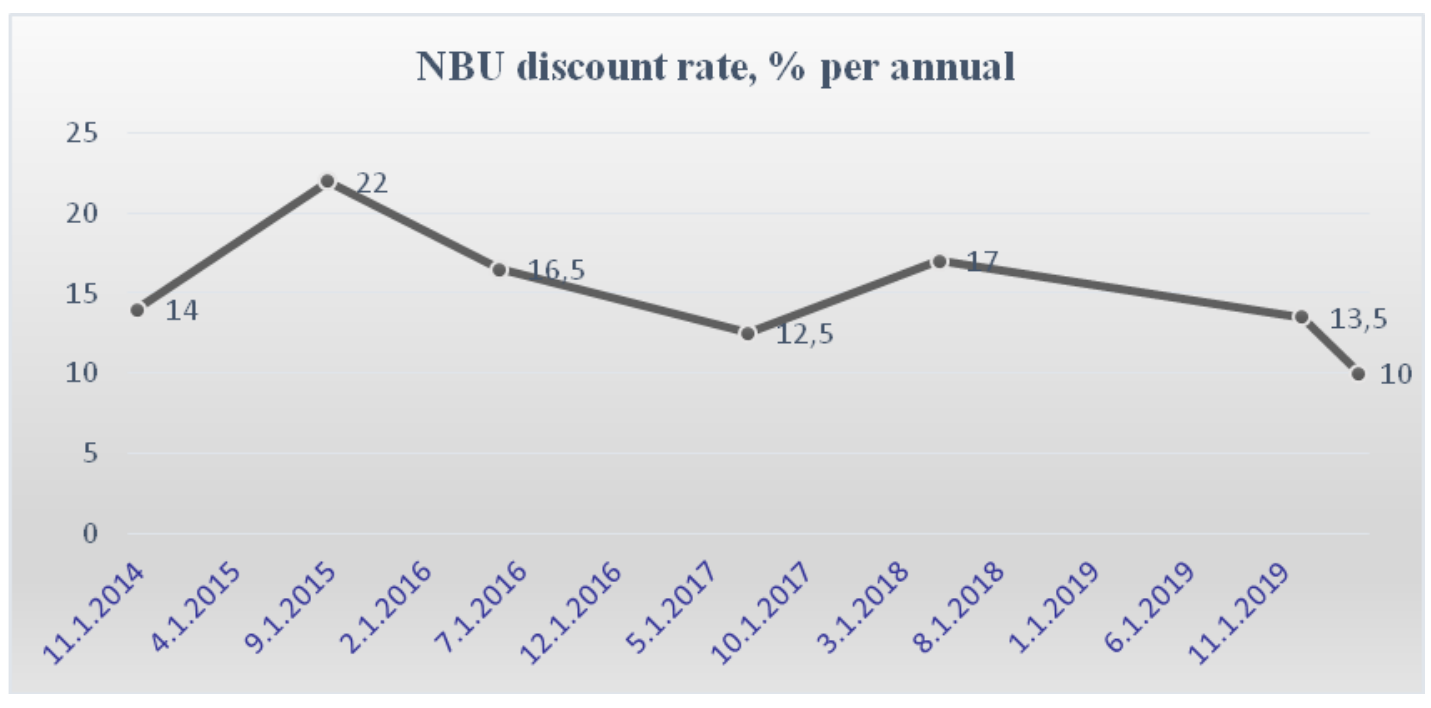

Pic. 2 - NBU discount rate, \% per annual. Source: formed by authors according to data [5].

It is clear that the quarantine, which has imposed in the country, has had the greatest impact on the banks' settlement and credit operations. The quarantine declared in Ukraine has so far restricted the movement of citizens and the use of a wide range of services, including banking services, so banks are forced to introduce new approaches to customer services.

So let's consider the most popular anti-crisis measures that banks apply to these banking services.

As paper money is now the source of coronavirus distribution, it is recommended for individuals and legal entities in the spring of 2020 period maximize all payments on-line, for which banks must develop and monitor the functionality of their mobile applications.

During the period of the imposed quarantine, banks offer their clients remote service, which in turn is a convenient and safe solution for both the bank and its clients.

For example, Privatbank offers free services for remote document management with a qualified electronic signature (QES). They help to create and display invoices to counterparties, acts of handing over and acceptance of completed works and contracts, as well as to register tax 
invoices via the Internet bank «Privat24 for business». Also an advantage of the program is the free and universal digital signature certificate for payments and records [7].

At the initiative of the NBU, the Verkhovna Rada prohibited from 1 March to 30 April the increase of the interest rate for the use of consumer credit for reasons other than the planned change of the floating interest rate under the contract. These changes apply to all individual loans. It is also prohibited to apply any liability (fines, penalties, etc.) for late performance of obligations between 1 March 2020 and 30 April 2020 [8].

Actual actions in support of quarantine for clients which are proposed by various banks are shown in Table 2.

Tab. 2 - Banking measures to support customers during the quarantine. Source: Created by the authors.

\begin{tabular}{|c|c|}
\hline Bank & Measures \\
\hline Privatbank & $\begin{array}{l}\text { 1) introduced a "credit holiday" for small and medium-sized business customers and entrepreneurs } \\
\text { from 01. 03. } 20 \text { until the end of May } 2020 \text {; } \\
2700 \text { miniPos terminals are operational, more than half of which are used by mail delivery } \\
\text { couriers. Portable trade terminals are also active in taxis and food delivery services; } \\
\text { 3) does not charge a fixed commission to traders who use the bank's POS terminals and have gone } \\
\text { into quarantine; } \\
\text { 4) at } 20.03 .20 \text { has expanded its list of securities services for its clients by enabling them to buy and } \\
\text { sell bonds of the domestic government loan online in the web version of Privat } 24 \text {; } \\
\text { 5) prolong the validity of payment cards (salary, pension, social cards) for } 90 \text { days if the card expires } \\
\text { during the quarantine period; } \\
\text { 6) since March } 18 \text {, PrivatBank has conducted currency exchange transactions for non-cash clients of } \\
\text { individuals through the Privat } 24 \text { mobile bank, Privat } 24 \text { web - version and the network of self- } \\
\text { service terminals [9]. }\end{array}$ \\
\hline Oschadbank & $\begin{array}{l}\text { 1) the ability to effectively use Oschad } 24 / 7 \text { - for individuals, Corp Light - for PIFs and legal entities, } \\
\text { chatbots and web chats; } \\
\text { 2) an opportunity to open a virtual prepaid card online for free, which can be replenished and } \\
\text { performed anywhere, anytime in Oschad } 24 / 7[10]\end{array}$ \\
\hline OTP Bank & $\begin{array}{l}\text { 1) remote credit repayment network: OTP Smart mobile application, online repayment on the Bank's } \\
\text { website - by a card of any Bank; } \\
\text { 2) reduction of credit repayment rates [11]. }\end{array}$ \\
\hline $\begin{array}{l}\text { Raiffeisen } \\
\text { Bank Aval }\end{array}$ & $\begin{array}{l}\text { 1) use of remote channels: for private clients - Raiffeisen Online; for business clients - Raiffeisen } \\
\text { Business Online; for premium clients - also through a personal manager; for corporate clients - } \\
\text { through a personal manager; } \\
\text { 2) cancellation of penalties and penalties for late payment of loans (from March } 1 \text { to April 30, 2020); } \\
\text { 3) two months free of charge for account servicing for credit cards "100 days", "Transparent", } \\
\text { Fishback, Fishka, "Basic", Platinum and Elite; } \\
\text { 4) for the quarantine period credit breaks are provided: reduction or cancellation of monthly } \\
\text { payment; } \\
\text { 5) the possibility of using payment cards, whose term of validity expires, is extended for } 90 \text { days } \\
\text { [12]. }\end{array}$ \\
\hline Alpha Bank & $\begin{array}{l}\text { 1) a credit vacation program for costumers that will give the opportunity to pause making payments } \\
\text { on their loan for two months; } \\
\text { 2) since March } 20 \text { until April 3, bank cardholders receive } 10 \% \text { cashback for payments in the most } \\
\text { popular category "Products" (including food delivery), as well as for taxis and online services; } \\
\text { 3) since March } 31 \text {, Alfa-Bank's business clients can replenish PIF accounts with cash in EasyPay } \\
\text { and City } 24 \text { terminal networks. The service is available all over Ukraine and operations are free of } \\
\text { charge. This measure avoids branch office visits and uses one of the nearest branching network } \\
\text { terminals; } \\
\text { 4) a new line of deposits in a mobile bank app with deposits of } 7 \text { days; } \\
\text { 5) the bank maintains all current credit card limits unchanged, allowing customers to secure the } \\
\text { necessary financial "pillow" till they come back to the job. The latest mobile bank update also } \\
\text { offered customers the option of instantly completing an online loan and increasing their credit } \\
\text { card limit [13]. }\end{array}$ \\
\hline
\end{tabular}

To sum it up, we have analysed anti-crisis measures, we believe that the most effective measures, taken to regulate banking activities under difficult economic conditions, are the following:

1) comfortable online service in mobile applications and increasing the number of possible transactions in these apps;
2) credit break during quarantine;

3) cancellation of the commission for the use of POSterminals and mobile applications;

4) extensions of expiring card life;

5) cashback for purchase of food products by card, payment of other services by card. 
All of these areas include preventing from the negative impact of the financial crisis under quarantine conditions on both the bank's customers and their trust to the bank and the bank itself, and supporting their clients in crisis situations. We believe that all of these measures are necessary and have a significant impact on reducing the incidence of coronavirus.

\section{Conclusions}

In the course of the study, the general state of banking services in accordance with conditions of coronavirus distribution and introduction of quarantine in the territory of Ukraine have been analyzed. As a result, the main activities that banks use to continue serving customers have been identified and highlighted. The authors illuminated the concept of «anti-crisis regulation» and considered methods and instruments of such regulation, defined the main direction of development of banking services in crisis conditions.
So, according to the study, now the banking sector in Ukraine is in crisis. Banks are forced to operate in uncertain conditions and to organize methods and measures for stable work with customers under the difficult conditions. During the period of the imposed quarantine, banks offer remote service for the clients, which in turn is a convenient and safe solution for both the bank and its clients.

After the analyze of the measures of the leading banks in Ukraine during this period, we have identified the main anti-crisis measures that have been introduced in most of them, namely:
1) provision of credit holidays;
2) stabilization of online applications functioning;
3) reducing the commission and so on.

\section{References}

1. Pro banky i bankivs'ku diyal'nist': Zakon Ukrayiny vid 07.12.2000 №2121 [About Banks and Banking: Law of Ukraine dated 07.12.2000 №2121]. Retrieved from: https://zakon.rada.gov.ua/laws/show/2121-14/conv [in Ukrainian].

2. Stubaylo, T.S. (2013). Bankivs'ki kryzy: prychyny ta naslidky [Banking crises: causes and consequences]. Innovatsiyna ekonomika - Innovative economy, 11(49), 168 - 174 [in Ukrainian].

3. Pokatayeva, O. V. \& Davydkova, N. M. (2014). Pidkhid do otsinky rozvytku rynku bankivs'kykh posluh [Approach to assessing the development of the banking services market]. Ekonomika ta derzhava - Economy and the state, $8,22-26$ [in Ukrainian].

4. Statystyka Natsional'noho banku Ukrayiny [Statistics of the National Bank of Ukraine]. Retrieved from: https://bank.gov.ua/statistic/supervision-statist/data-supervision\#1 [in Ukrainian].

5. Statystyka Natsional'noho banku Ukrayiny [Statistics of the National Bank of Ukraine]. Retrieved from: https://bank.gov.ua/statistic/sector-financial/data-sector-financial\#2fs [in Ukrainian].

6. Sayt novyn «Biznes Tsenzor» [Site of news: "Business Censor"]. Retrieved from:https://biz.censor.net.ua/resonance/3165041/scho_oznacha_znijennya_oblkovo_stavki_natsonalnogo_bank $\mathrm{u}$ [in Ukrainian].

7. Pryvat24 dlya biznesu [Privat24 for business]. Retrieved from: https://otp24.privatbank.ua/v3/\#!/news/1381730 [in Ukrainian].

8. Natsional'nyy bank Ukrayiny [National Bank of Ukraine]. Retrieved from: https://bank.gov.ua/about/covid19 [in Ukrainian].

9. Pryvatbank: veb - sayt [Privatbank: website]. Retrieved from: https://privatbank.ua/ [in Ukrainian].

10. Oshchadbank: veb - sayt. [Oshchadbank : website]. Retrieved from: https://www.oschadbank.ua/ [in Ukrainian].

11. OTP Bank: veb - sayt. [OTP Bank: website]. Retrieved from: https://www.otpbank.com.ua/ [in Ukrainian].

12. Rayffayzen Bank Aval': veb - sayt [Raiffeisen Bank Aval: website]. Retrieved from: https://www.aval.ua/ [in Ukrainian].

13. Al'fa Bank: veb - sayt [ Alpha Bank: website]. Retrieved from: https://alfabank.ua/ [in Ukrainian].

14. Baranovs'kyy, O. I. (2009). Antykryzovi zakhody uryadiv i tsentral'nykh bankiv zarubizhnykh krayin [Anticrisis measures of governments and central banks of foreign countries.]. Visnyk Natsional'noho banku Ukrayiny - Bulletin of the National Bank of Ukraine, 4, 8-19. 